\title{
Analisis Pengaruh Citra Merek, Harga dan Kualitas Produk Terhadap Keputusan Pembelian Produk Kosmetik Wardah
}

\author{
Muryati*, Ade Jermawinsyah Zebua \\ Sekolah Tinggi Ilmu Ekonomi Graha Karya Muara Bulian Jambi \\ *Correspondence email: dra.muryati@gmail.com
}

\begin{abstract}
Abstrak. Tujuan penelitian ini yaitu untuk mengetahui pengaruh variabel citra merek, harga dan kualitas produk secara parsial dan simultan terhadap keputusan pembelian produk lipstick wardah,selain itu juga untuk mengetahui variabel yang paling dominan dalam pengambilan keputusan pembelian lipstick wardah Penelitian ini merupakan penelitian kausal komparatif dengan pendekatan kuantitatif. Variabel dalam penelitian ini adalah citra merek,harga, kualitas produk dan keputusan pembelian sebagai variabel terikat. Populasi pada penelitian seluruh mahasiswi semester VI Pada Sekolah Tinggi Ilmu Ekonomi Graha Karya Muara Bulian yaitu berjumlah 40 responden. Dari hasil penelitian menunjukkan bahwa pengaruh citra merek, harga dan kualitas produk secara parsial dari masing-masing variabel berpengaruh positif dan signifikan terhadap keputusan pembelian sedangkan secara simultan semиa variabel X1, X2 dan X3 berpengaruh positif dan signifikan terhadap keputusan pembelian Lipstick wardah pada mahasiswi semester VI Sekolah Tinggi Ilmu Ekonomi Graha Karya Muara Bulian. Dari hasil analisa menunjukkan bahwa Nilai Adjusted $R$ Square sebesar 0,623 artinya variabel citra merek, harga dan kualitas produk 62,3\% mempengaruhi keputusan pembelian lipstick wardah dan lebihnya sebesar $37,7 \%$ dipengaruhi oleh variabel lain yang tidak diteliti dalam penelitian ini.
\end{abstract}

Kata Kunci: Citra Merek; Harga; Kualitas Produk dan Keputusan Pembelian.

\begin{abstract}
The purpose of this study is to determine the effect of the variable brand image, price and product quality partially and simultaneously on purchasing decisions for wardah lipstick products, in addition to knowing the most dominant variables in making wardah lipstick purchasing decisions. This research is a comparative causal research with a quantitative approach. . The variables in this study are brand image, price, product quality and purchasing decisions as the dependent variable. The population in the study were all sixth semester students at the Graha Karya Muara Bulian School of Economics, which amounted to 40 respondents. The results of the study indicate that the influence of brand image, price and product quality partially from each variable has a positive and significant effect on purchasing decisions while simultaneously all variables X1, X2 and X3 have a positive and significant effect on purchasing decisions Lipstick wardah in sixth semester female students. Graha Karya Muara Bulian School of Economics. From the analysis results indicate that the Adjusted $R$ Square value of 0.623 means that the variable brand image, price and product quality $62.3 \%$ affect the purchasing decision of Wardah lipstick and $37.7 \%$ is influenced by other variables not examined in this study.
\end{abstract}

Keywords: Brand Image; Price; Product Quality and Purchase Decision.

\section{PENDAHULUAN}

Tampak menawan ialah idaman tiap perempuan supaya dapat menarik serta tampak beda supaya dikagumi seluruh orang. Kemauan tampak menawan serta menarik merupakan idaman tiap perempuan. Ratarata wanita ingin tampil menarik dan sempurna. Konsumen biasanya memilih produk kecantikan dan alat kosmetik yang sesuai dan cocok dengan jenis kulit mereka.

Meningkatkatnya minat beli produk kecantikan dan kosmetik memunculkan persaingan di dunia industri menjadi kompetitif. Hal ini bisa dilihat dari banyaknya tipe kosmetik yang tersebar di pasar, baik yang dibuat dalam negeri ataupun luar negeri. Keberagaman produk kecantikan yang terdapat di pasar, nyatanya mempengaruhi perilaku seorang dalam memilah produk kecantikan yang cocok dengan kulitnya, serta tidak mempunyai efek samping ataupun dampak yang beresiko untuk kesehatan kulit.

Saat ini banyak produk kecantikan atau alat kosmetik yang terdapat dipasaran antara lain: Maybelline, Wardah, Oriflame, Pixy dan lain sebagainya. Dari bermacam merk tersebut salah satu merk kecantikan yang hendak diteliti merupakan lipstik Wardah, sebab lipstik Wardah telah jadi salah satu kebutuhan kecantikan untuk kalangan perempuan. Sebab persaingan produk kecantikan yang terus menjadi lama terus menjadi tumbuh hingga tiap produsen dituntut buat bisa berinovasi pada produknya sehingga mencuat produk yang baru serta diminati oleh konsumen. Tidak hanya itu produsen dituntut buat mengenali pangsa pasar yang dituju salah satu triknya merupakan produsen wajib mengenali sikap konsumen. (Hariyawati 2017)

Kotler P \& Keller (2013) sikap konsumen merupakan riset tentang gimana orang, kelompok serta organisasi memilah, membeli, memakai serta gimana benda, jasa, ilham ataupun pengalaman buat memuaskan kebutuhan kemauan mereka.

Yang bisa mempengaruhi keputusan pembelian salah satu aspeknya adalah citra merk. Kotler P \& Keller 
(2013) merasakan suatu pengalaman yang mereka rasakan serta meyakini sesuatu tersebut adalah cocok yang tertanam dalam ingatan mereka. Citra merk hendaknya bisa mempengaruhi konsumen dalam membeli suatu produk. Umumnya, konsumen beranggapan bawa produk dari merk tersebut adalah baik, harga yang ditawarkan mesti sebanding dengan kualitas produknya. Sebab, telah tertanam dalam ingatan mereka bahwa citra merk produk tersebut adalah baik. Perihal tersebut pula jadi salah satu aspek yang pengaruhi pembelian pada konsumen. Menurut Tjiptono (2012) keputusan pembelian ialah aksi orang yang secara langsung ataupun tidak langsung ikut serta dalam usaha mendapatkan serta memakai sesuatu produk ataupun jasa yang diperlukan.

Aspek berikutnya yang pengaruhi keputusan pembelian merupakan harga produk. Kotler $\mathrm{P}$ \& Amstrong (2013) harga merupakan sesuatu yang dibebankan atas suatu benda ataupun jasa ataupun jumlah dari nilai yang diganti konsumen atas manfaatmanfaat sebab mempunyai ataupun memakai produk ataupun jasa tersebut. Buat menetapkan harga sesuatu produk, hingga industri wajib bisa membiasakan harga dengan mutu produk yang hendak ditawarkan, sebab jika harga yang ditawarkan sudah cocok dengan mutu produk sehingga membuat konsumen menjadi tertarik untuk membelinya.

Aspek berikutnya yang pengaruhi keputusan pembelian merupakan mutu produk. Menurut Kotler P \& Amstrong (2013) Mutu produk merupakan seluruh suatu yang bisa ditawarkan kepasar buat memperoleh atensi, dibeli, digunakan, ataupun disantap yang bisa memuaskan kemauan ataupun kebutuhan. Konsumen mengharapkan mutu yang ditawarkan oleh produsen cocok dengan ekspektasi yang di mau konsumen. Sebab, terus menjadi baik mutu dari suatu produk hingga terus menjadi besar kemauan konsumen dalam melaksanakan pembelian secara kesekian ulang. Produk kecantikan perempuan terdiri dari bermacam berbagai tipe ialah tercantum produk lipstik. Lipstik merupakan kosmetik yang biasanya digunakan buat membuat cantik bibir.

\section{METODE}

\section{Populasi dan Sampel}

Populasi dari penelitian ini adalah mahasiswa semester VI STIE Graha Karya Muara Bulian yang berjumlah 40 mahasiswi. Penentuan sampel dalam penelitian menurut (Sugiyono 2012) jika populasi kurang dari 100 orang sebaiknya diambil semua, jika obyeknya besar atau lebih besar dari 100 orang maka sampel bisa diambil $10-15 \%$ atau $20-25 \%$. Dalam penelitian ini kuesioner disebarkan secara acak kepada seluruh responden walaupun mahasiswa tersebut tidak memakai produk lipstick wardah.

Dalam penelitian ini terdapat 2 variabel yaitu variabel terikat dan variabel bebas atau variabel bebas dan variabel terikat. Variabel yang termasuk dalam penelitian ini terdiri dari dua macam variabel, yaitu variabel terikat atau variabel yang bergantung pada variabel lain, dan variabel bebas atau variabel yang tidak bergantung pada variabel lain. Variabel terikat dalam penelitian ini adalah Keputusan Pembelian (Y), sedangkan variabel bebasnya adalah $(\mathrm{X})$ yang meliputi 3 dimensi yaitu Citra Merek (X1), Harga (X2), dan Kualitas Produk (X3).

Penyebaran kuesioner dan skala pengukuran data menggunakan skala Likert. Dari setiap instrumen jawaban setiap item memiliki gradasi dari sangat negatif hingga sangat positif dan untuk keperluan analisis kuantitatif jawaban dapat dinilai sebagai berikut:

1. Sangat Tidak Setuju(STS $)=1$,

2. Tidak Setuju $(\mathrm{TS})=2$,

3. Diragukan $(\mathrm{RG})=3$,

4. Setuju $(S)=4$

5. Sangat Setuju $=5$

Data yang telah terkumpul kemudian dianalisis dan diolah sehingga hasilnya dapat digunakan sebagai dasar pengambilan keputusan, analisis data penelitian ini metode statistik menggunakan SPSS for windows versi 20.

\section{Uji Validitas dan Uji Reliabilitas Uji Validitas}

Buat menunjang analisis regeresi, uji validitas serta uji reliabilitas dicoba. Uji validitas dalam riset ini digunakan buat menguji validitas kuesioner. melaksanakan guna perlengkapan ukur (Moloeng and Lexy 2012). Pengukuran validitas bisa dicoba memakai 3 pendekatan:

1. Validitas Konten

Ini adalah konsep pengukuran validitas di mana instrumen dinilai memiliki validitas isi, jika memiliki butir masalah yang cukup dan representatif untuk membangun kecocokan dengan yang diinginkan peneliti.

2. Kriteria Terpaut Validitas

Ini adalah konsep pengukuran validitas yang menguji keakuratan instrumen yang baru diangkat. Uji validitas terpaut kriteria dicoba dengan menghitung koefisien korelasi antara skor yang diperoleh dari penggunaan instrumen baru dan skor dari penggunaan instrumen lain yang sudah ada yang memiliki kriteria relevan.

3. Uji Validitas

Ini adalah konsep mengukur validitas dengan memeriksa apakah suatu instrumen mengukur konstruk yang diharapkan.

\section{Uji Realibilitas}

Uji reliabilitas merupakan indeks yang menampilkan sejauh mana hasil penelitian 
pengukuran dapat dipercaya. Hasil yang terukur hanya dapat diandalkan atau diandalkan dalam hal beberapa pengukuran dari kelompok subjek yang sama, selama aspek yang diukur dalam subjek tidak berubah. Uji reliabilitas dapat diukur dengan 3 pendekatan yang tercantum:

1. Koefisien stabilitas

Pendekatan ini pada dasarnya untuk menentukan keandalan informasi berdasarkan stabilitas atau konsistensi jawaban responden.

2. Koefisien kesetaraan

Pendekatan ini lebih menekankan pada berbagai bentuk instrumen. Di sisi lain, subjek penelitian, konstruksi dan periode pengukuran adalah sama.

3. Keandalan Konsistensi Internal

Konsep reliabilitas untuk pendekatan ini adalah konsistensi antara masalah atau pernyataan dalam suatu instrumen.

\section{Analisa Koefisien Diterminasi}

Koefisien determinasi ( $\mathrm{R}^{2}$ ) dimaksudkan untuk memastikan tingkat akurasi terbaik dalam analisis regresi, yang ditunjukkan dengan besarnya koefisien determinasi ( $\mathrm{R}^{2}$ ) antara 0 ( nol) dan 1 ( satu). Koefisien determinasi $\left(\mathrm{R}^{2}\right)$ nol variabel bebas tidak berpengaruh terhadap variabel terikat. Jika koefisien determinasi mendekati satu, maka dapat dikatakan bahwa variabel bebas mempengaruhi variabel terikat. Selain itu, koefisien determinasi digunakan untuk mengetahui persentase perubahan variabel terikat (Y) yang disebabkan oleh variabel bebas (X).

\section{Uji t (Uji Signifikansi Parsial)}

Uji t digunakan untuk menguji signifikansi ikatan antara variabel $\mathrm{X}$ dan variabel $\mathrm{Y}$, apakah variabel $\mathrm{X} 1$, $\mathrm{X} 2$, X3 benar-benar mempengaruhi variabel $\mathrm{Y}$. Hipotesis nol (H0) yang akan diuji adalah parameter (p) sama dengan nol

\section{H0:p= 0}

Artinya apakah variabel bebas tidak merupakan gambaran yang signifikan terhadap variabel terikat. Parameter hipotesis alternatif ( $\mathrm{Ha}$ ) suatu variabel tidak sama dengan nol atau:

\section{Ha:pÇ 0}

Artinya variabel bebas merupakan penjelas yang signifikan terhadap variabel penjelas. Jika $\mathrm{t}$ hitung \& $\mathrm{t}$ tabel, sampai H0 diterima yang artinya tidak ada pengaruh antara masing-masing variabel $\mathrm{X}$ dan variabel Y. Jika t hitung, $t$ tabel, sampai H0 ditolak yang berarti terdapat pengaruh antara masing-masing variabel; $\mathrm{X}$ dengan $\mathrm{Y}$

\section{Uji F (Uji Signifikansi Simultan)}

Dalam penelitian ini, untuk mengidentifikasi tingkat signifikansi pengaruh variabel independen secara simultan terhadap variabel dependen, dicoba menggunakan uji $\mathrm{F}$, yaitu menyamakan $\mathrm{F}$ hitung dengan F tabel. Hipotesis nol (H0) yang akan diuji adalah apakah semua parameter dalam model sama dengan nol atau

\section{H0: $p=0$}

Hal ini berarti bahwa semua variabel bebas merupakan deskripsi yang tidak signifikan terhadap variabel terikat. Hipotesis alternatif (Ha) tidak semua parameter bertepatan dengan nol.

\section{Ha:bÇ 0}

Artinya semua variabel independen secara simultan merupakan deskripsi signifikan dari variabel dependen. Ketika f Hitung\&lt; F Tabel sampai Ho diterima dan Ha ditolak, artinya tidak ada pengaruh simultan. Ketika $\mathrm{F}$ menghitung, F tabel, sampai HO ditolak dan Ha diterima berarti ada pengaruh simultan.

\section{HASIL DAN PEMBAHASAN}

\section{Karakteristik Responden berdasarkan jenis kelamin}

Jenis kelamin merupakan pembedaan perilaku seseorang dalam berperilaku, penyajian data responden dapat dilihat sebagai berikut:

Tabel 1. Karakteristi Responden Berdasarkan Jenis Kelamin

\begin{tabular}{lcc}
\hline Jenis Kelamin & Total & Pesrentase (\%) \\
\hline Wanita & 40 & 100 \\
Total & 40 & 100 \\
\hline
\end{tabular}

Sumber Data: Data diolah

\section{Karakteristik Responden berdasarkan usia}

Perilaku individu menunjukkan gambaran pengalaman dan tanggung jawab individu, hal ini dapat dilihat dari usia. Tabulasi usia dapat dilihat sebagai berikut:

Tabel 2. Karakteristi Responden Berdasarkan Usia

\begin{tabular}{ccc}
\hline Umur & Jumlah & Pesrentase $(\%)$ \\
\hline$\leq 20$ th & 22 & 55 \\
$21-22$ Th & 15 & 37,5 \\
$23-24$ Th & 3 & 7,5 \\
$>25$ Tahun & 0 & 0 \\
Jumlah & 40 & 100 \\
\hline
\end{tabular}

Sumber Data: Data diolah

\section{Uji Validitas}

Hasil Uji Validitas digunakan untuk menguji keakuratan pengukuran untuk mengungkap fenomena. Uji validitas ini dilakukan dengan menggunakan rumus korelasi untuk menyebarkan kuesioner dengan hasil sebagai berikut: 
Muryati dan Ade Jermawinsyah Zebua, Analisis Pengaruh Citra Merek, Harga dan Kualitas Produk Terhadap Keputusan Pembelian Produk Kosmetik Wardah

Tabel 3 : Uji Validitas

\begin{tabular}{lccc}
\hline \multicolumn{1}{c}{ Indikator } & R Hitung & R Tabel & Diskripsi \\
\hline Citra Merek & & & \\
P1 & 0,636 & 0,3246 & Valid \\
P2 & 0,681 & 0,3246 & Valid \\
P3 & 0,595 & 0,3246 & Valid \\
P4 & 0,630 & 0,3246 & Valid \\
P5 & 0,702 & 0,3246 & Valid \\
Harga & & & \\
P1 & 0,522 & 0,3246 & Valid \\
P2 & 0,617 & 0,3246 & Valid \\
P3 & 0,764 & 0,3246 & Valid \\
P4 & 0,858 & 0,3246 & Valid \\
P5 & 0,555 & 0,3246 & Valid \\
Kualitas Produk & & & \\
P1 & 0,663 & 0,3246 & Valid \\
P2 & 0,712 & 0,3246 & Valid \\
P3 & 0,681 & 0,3246 & Valid \\
P4 & 0,770 & 0,3246 & Valid \\
P5 & 0,770 & 0,3246 & Valid \\
& 0,731 & 0,3246 & Valid \\
Keputusan Pembelian & & & \\
P1 & 0,693 & 0,3246 & Valid \\
P2 & 0,689 & 0,3246 & Valid \\
P3 & 0,704 & 0,3246 & Valid \\
P4 & 0,783 & 0,3246 & Valid \\
\hline Sumber: Data Diolah & & &
\end{tabular}

Sumber: Data Diolah

Tabel di atas menunjukkan bahwa semua indikator untuk mengukur variabel yang digunakan dalam penelitian ini memiliki koefisien korelasi lebih besar dari $r$ tabel $=0,3246$ dari 40 responden, artinya semua indikator dinyatakan valid.

\section{Uji Reliabilitas}

Uji reliabilitas digunakan untuk menguji sejauh mana reliabilitas alat ukur dapat digunakan kembali untuk penelitian yang sama. Pengujian reliabilitas dalam penelitian ini menggunakan rumus Alpha Cronbach.

Tabel 4. Reliabilitas

\begin{tabular}{|l|c|c|c|}
\hline Variabel & $\begin{array}{c}\text { Cronbach } \\
\text { Alpha }\end{array}$ & $\begin{array}{c}\text { Batas } \\
\text { Reliabilitas }\end{array}$ & Diskripsi \\
\hline Citara Merek & 0,674 & 0,6 & Riliabel \\
Harga & 0,700 & 0,6 & Riliabel \\
Kualitas Produk & 0,756 & 0,6 & Riliabel \\
Keputusan Pembelian & 0,666 & 0,6 & Reliabel \\
\hline
\end{tabular}

Sumber: Data Diolah

Hasil uji reliabilitas variabel-variabel yang digunakan dalam penelitian ini diperoleh nilai alpha lebih besar dari 0,60 yang artinya variabel-variabel dalam penelitian ini dapat digunakan

\section{Koefisien Determinasi (R2)}

Koefisien determinasi mengukur sejauh mana kemampuan model dalam menjelaskan variasi variabel terikat. Hasil perhitungan koefisien determinasi dapat dilihat sebagai berikut:
Tabel 5. Model Summary

\begin{tabular}{|c|c|c|c|c|}
\hline Model & $\mathrm{R}$ & $\begin{array}{c}\mathrm{R} \\
\text { Square }\end{array}$ & $\begin{array}{c}\text { Adjusted R } \\
\text { Square }\end{array}$ & $\begin{array}{c}\text { Std Error of the } \\
\text { Estimate }\end{array}$ \\
\hline 1 &, $617^{\mathrm{a}}$ &, 367 &, 623 & 2,88184 \\
\hline
\end{tabular}

a. Predictors: (Constant),Kualitas Produk, Harga, Citra Merek

Sumber: Data Diolah

Dapat dilihat dari tabel 5 bahwa koefisien terminasi (Adjusted R Square) diperoleh sebesar 0,623 yang menunjukkan bahwa Citra Merek, Harga, Kualitas Produk secara simultan memberikan kontribusi sebesar 62,3\% terhadap Keputusan Pembelian sedangkan 37,7\% dipengaruhi oleh variabel yang tidak diteliti.

\section{Uji $F$}

Pengujian simultan atau uji $F$ menunjukkan apakah semua variabel bebas yang dimasukkan dalam model memiliki pengaruh co-dependen terhadap variabel terikat, perhitungan uji $\mathrm{F}$ adalah sebagai berikut:

Tabel 6. ANOVA

\begin{tabular}{|ll|r|c|c|c|c|}
\hline Model & $\begin{array}{c}\text { Sum Of } \\
\text { Square }\end{array}$ & df & $\begin{array}{c}\text { Mean } \\
\text { Square }\end{array}$ & F & Sig. \\
\hline Regression & 88,424 & 3 & 33,746 & 7,726 & \\
1 & $\begin{array}{r}\text { Residual } \\
\text { Total }\end{array}$ & $\begin{aligned} 139,460 \\
\text { b }\end{aligned}$ & 36 & 5,725 & & $001^{\mathrm{b}}$ \\
\hline
\end{tabular}

a. Dependent Variable : Keputusan Pembelian

b. Predictors : (Constant), Kualitas Produk, Harga, Citra Merek

Sumber: Data Diolah

Hasil pengujian berdasarkan uji ANOVA atau uji statistik F, model menunjukkan nilai $\mathrm{F}$ sebesar 7,726 dengan probabilitas 0,000. Nilai signifikan lebih kecil dari 0,050 artinya Citra Merek, Harga, Kualitas Produk secara bersama-sama mempengaruhi keputusan pembelian lipstik Wardah.

\section{Uji $t$}

Tabel 7. Coefficients ${ }^{\mathrm{a}}$

\begin{tabular}{|ll|r|r|r|r|r|}
\hline \multirow{2}{*}{ Model } & \multicolumn{2}{|c|}{$\begin{array}{c}\text { Unstandardized } \\
\text { Coefficients }\end{array}$} & $\begin{array}{c}\text { Standardized } \\
\text { Coefficients }\end{array}$ & \multirow{2}{*}{ t } & \multirow{2}{*}{ Sig. } \\
\cline { 3 - 5 } & \multicolumn{1}{|c|}{ B } & Std. Error & \multicolumn{1}{c|}{ Beta } & & \\
\hline \multirow{2}{*}{1} & (Constant) & 2,657 & 8,965 & &, 653 &, 428 \\
& Citra Merek &, 206 &, 156 &, 468 & 3,423 &, 001 \\
& Harga &, 629 & 1,62 &, 616 & 2,562 &, 001 \\
& Kualitas Produk &, 246 &, 203 &, 212 & 2,836 &, 001 \\
\hline
\end{tabular}

a.Dependent Variable: Keputusan Pembelian

Sumber: Data Diolah

Hasil uji t menguji sejauh mana pengaruh satu variabel independen secara individual dalam menjelaskan variasi variabel dependen. Dari Tabel 7 dapat dilihat bahwa variabel Independen X1, X2 dan X3 memiliki tingkat signifikansi lebih kecil dari 0,05. Yang berarti bahwa variabel $\mathrm{X} 1, \mathrm{X} 2$ dan $\mathrm{X} 3$ secara independen berpengaruh signifikan terhadap variabel dependen (Y). 


\section{Pembahasan}

Hasil penelitian ini mendukung konsep (Kotler P \& Keller 2012) dan (Andikarini 2017) yang berpendapat bahwa citra positif suatu merek produk akan mendorong konsumen untuk melakukan pembelian terhadap produk yang bersangkutan. Jadi pada dasarnya citra merek yang positif diharapkan dapat diciptakan oleh suatu industri. Produk yang memiliki citra merek yang baik ingin membagikan rasa aman dan pemikiran positif masyarakat tentang produk tersebut, dan selanjutnya memperkuat keputusan pembelian mereka terhadap produk tersebut sehingga volume penjualan menghadapi peningkatan.

Keputusan pembelian lipstik wardah dalam riset ini dipengaruhi secara positif oleh variabel citra merk, harga serta mutu produk, hingga disimpulkan kalau hipotesis yang sudah didetetapkan bisa diterima. Sehabis dicoba riset kalau lipstik wardah sangat disukai oleh konsumen serta konsumen merasa puas sebab mutu yang baik serta harga terjangkau serta nyaman untuk pemakainya.

Hasil analisis penelitian ini semakin menegaskan bahwa harga berpengaruh positif dan signifikan terhadap keputusan pembelian konsumen terhadap produk. Hasil penelitian ini sesuai dengan alasan (Ayuniah 2017) bahwa harga memiliki 2 peran utama dalam proses pengambilan keputusan pembelian, yaitu peran alokasi dan peran data. Kedua posisi tersebut telah diuji pengaruhnya secara positif dan signifikan terhadap keputusan pembelian konsumen. Bagi (Tjiptono 2012) peran alokasi adalah menggunakan harga dalam membantu pembeli untuk mendapatkan manfaat atau utilitas tertinggi yang diharapkan berasal dari sumber pembelian energi. Dengan demikian, keberadaan harga dapat membantu pembeli untuk memutuskan bagaimana mengalokasikan energi pembeliannya ke berbagai jenis barang dan jasa. Pembeli menyamakan harga dari berbagai alternatif, setelah itu mereka memutuskan alokasi dana yang diinginkan.

Hasil analisis penelitian ini juga menegaskan bahwa kualitas produk berpengaruh positif dan signifikan terhadap keputusan pembelian konsumen, salah satu produk Wardah adalah lipstik. Penelitian ini menunjukkan bahwa kualitas produk berkaitan erat dengan keputusan pembelian, dimana kualitas produk merupakan salah satu aspek pertimbangan konsumen dalam mengambil keputusan pembelian. Kualitas produk menjamin keputusan pembelian seorang konsumen, yang terus menjadi produk yang berkualitas sampai terus menjadi keputusan konsumen yang solid untuk melakukan pembelian terhadap produk tersebut.

Hasil analisis terakhir meyakinkan bahwa tidak hanya masing-masing memiliki pengaruh positif dan signifikan, secara simultan ketiga variabel bebas yang dibahas dalam penelitian ini telah diuji memiliki pengaruh yang signifikan terhadap keputusan pembelian konsumen. Dengan demikian, produsen perlu memikirkan baik citra merek, kualitas produk maupun harga secara bersama-sama dalam menentukan strategi pemasaran produk lipstik Wardahnya, karena terbukti sangat mempengaruhi terciptanya keputusan pembelian konsumen terhadap produk tersebut. Hasil analisis terbaru juga memperluas temuan empiris yang diperoleh (Prasatiningtyas 2016), (Ayuniah 2017) dan (Supangkat 2017) yang melaporkan bahwa citra merek, kualitas produk dan harga memiliki pengaruh yang signifikan terhadap keputusan pembelian.

\section{SIMPULAN}

Dari hasil analisis informasi dapat disimpulkan bahwa citra merek, harga dan kualitas produk berpengaruh signifikan terhadap keputusan pembelian oleh konsumen terhadap produk lipstik wardah, baik secara parsial maupun simultan. Variabel citra merek diidentifikasi sebagai aspek yang sangat dominan pengaruhnya terhadap keputusan pembelian dibandingkan dengan dua aspek independen lainnya.

Dari kesimpulan di atas untuk mencuat beberapa saran. Awalnya, industri yang memproduksi produk lipstik wardah diharapkan dapat terus menjaga dan meningkatkan brand image yang baik di benak konsumen atas produk tersebut. Upaya yang dapat dicoba antara lain mengamati kesamaan antara kebutuhan konsumen dengan produk yang dihasilkan, dan terus menghasilkan keunggulan yang berbeda dibandingkan produk merek pesaing yang serupa.

Saran kedua sebaiknya juga menawarkan harga yang sesuai dengan kualitas produk yang diberikan oleh produk lipstik Wardah. Dalam arti, jika harga dinaikkan agar kualitas produk yang dihasilkan juga harus ditingkatkan. Yang terpenting, jangan sampai harga yang ditawarkan jauh lebih besar dari harga yang diumumkan kompetitor.

Industri juga diharapkan dapat menjaga konsistensi kualitas produk dan meningkatkan kualitas sesuai dengan harapan konsumen, misalnya dengan melakukan inovasi-inovasi baru termasuk kandungan dan aroma baru yang sesuai dengan kebutuhan konsumen. Upaya ini diharapkan dapat membuat konsumen merasa percaya diri dan percaya diri terhadap produk lipstik Wardah.

Diharapkan untuk penelitian selanjutnya, variabel yang diteliti tidak terbatas pada citra merek, harga dan kualitas produk. Karena berdasarkan hasil penelitian ini diketahui bahwa masih banyak variabel lain yang dapat mempengaruhi keputusan pembelian, seperti atribut produk, kegiatan promosi, penentuan posisi penjualan, kualitas pelayanan, dan lain-lain. Dengan upaya tersebut, pihaknya terus memperdalam uraian mengenai faktorfaktor yang mempengaruhi keputusan pembelian oleh konsumen khususnya untuk produk lipstik wardah. 


\section{DAFTAR PUSTAKA}

Andikarini. 2017. "Pengaruh Kualitas Produk, Citra Merek, Dan Harga Terhadap Keputusan Pembelian Lipstick Wardah Di Yogyakarta." Skripsi Fakultas Ekonomi Universitas Sanata Dharma.

Ayuniah, Putri. 2017. "Analisis Pengaruh Citra Merek, Kualitas Produk, Iklan, Dan Harga Terhadap Keputusan Pembelian Produk Kosmetik Wardah (Studi Kasus Pada Mahasiswi Jurusan Manajemen Fakultas Ekonomi Universitas Gunadarma Yang Mengambil Kuliah Di Kampus Depok)" edited by Andi. Jurnal Ekonomi Bisnis 22(3):208-19. doi: 10.35760/eb.

Hariyawati, Mega Ayu WP dan Susi. 2017. "Pengaruh Citra Merek Dan Kualitas Produk Terhadap Keputusan Konsumen Membeli Produk Jam Tangan Merek Casio."

Kotler P \& Amstrong. 2013. Prinsip Prinsip Pemasaran. Jakarta: Erlangga.

Kotler P \& Keller. 2012. Manajemen Pemasaran. 14th ed. Jakarta: Indeks.

Kotler P \& Keller. 2013. Manajemen Pemasaran. Jakarta: Erlangga.

Moloeng, and J. Lexy. 2012. Metodologi Penelitian Kualitatif. Bandung: PT Remaja Rosdakarya Offset.

Prasatiningtyas, T. .. 2016. "Pengaruh Citra Merek, Kualitas Produk Harga Dan Harga Terhadap Keputusan Pembelian Kartu Seluler Telkomsel Pada Karya- Wan Karyawan PT. Sentral Bahana Ekatama Surabaya." Jurnal Ilmu Riset Dan Manajemen 5:15.

Sugiyono. 2012. Metode Penelitian Bisnis. Bandung: Alfabeta.

Supangkat, A. H. 2017. "Pengaruh Citra Merek, Kualitas Produk Dan Harga Terhadap Keputusan Pembelian Tas Di Intako.” Jurnal Ilmu Dan Riset Manajemen 6:1-9.

Tjiptono. 2012. Strategi Pemasaran. Yogyakarta: Andi. 